NJC

\title{
CORRECTION
}

View Article Online

View Journal I View Issue

D) Check for updates

Cite this: New J. Chem., 2018,

42, 12263

DOI: $10.1039 / c 8 n j 90059 k$

rsc.li/njc

The third author's name is spelt incorrectly in the published article. The correct author name is Hern Kim, as shown above. The Royal Society of Chemistry apologises for these errors and any consequent inconvenience to authors and readers.

\section{Correction: An effective electrochemical sensing platform for fluoride ions based on fluorescein isothiocyanate-MWCNT composite}

\author{
Richard Appiah-Ntiamoah,* Bekelcha Tesfaye Gadisa and Hern Kim* \\ Correction for 'An effective electrochemical sensing platform for fluoride ions based on fluorescein \\ isothiocyanate-MWCNT composite' by Richard Appiah-Ntiamoah et al., New J. Chem., 2018, DOI: \\ 10.1039/c8nj01703d.
}

